\title{
Cikkismertetés: Az iskolai klíma és az egészségi állapot javítása középiskolában
}

\author{
Article review: Promoting school climate and health outcomes in \\ secondary school
}

Ismertető: $\quad$ Kis Bernadett $\square$

Szegedi Tudományegyetem Juhász Gyula Pedagógusképző Kar, Alkalmazott Egészségtudományi és Egészségfejlesztési Intézet

Ismertetett cikk: Shinde S, Weiss HA, Varghese B et al. Promoting school climate and health outcomes with the SEHER multi-component secondary school intervention in Bihar, India: a clusterrandomised controlled trial. Lancet 2018; 392: 2465-77. doi: 10.1016/S0140$\underline{6736(18) 31615-5}$

Beküldve: $\quad$ 2019. 03. 27.

doi: $\quad$ 10.24365/ef.v60i2.443

Kulcsszavak: iskolai egészségfejlesztés; iskolai klíma; komplex egészségfejlesztő beavatkozás; serdülőkor; egészségi állapot

Keywords: school health promotion; school climate; complex health promotion intervention; adolescence; health outcomes

\section{HÁTTÉR}

Az iskolai klíma egyaránt befolyásolja az egészséget és a teljesítményt, ezért az iskolai társas környezet javítása kiemelt jelentőségú lehet a serdülők egészségének és jóllétének fejlesztésében, különösen az alacsony és közepes jövedelmű országokban, ahol nagy a középiskolai évismétlések aránya.

\section{MÓDSZER}

A tanulmány a SEHER' nevű komplex egészségfejlesztő beavatkozás hatékonyságát vizsgálta 13-14 évesek körében India egyik szövetségi államában, Bihárban. A szerzők tudomása szerint ez az első olyan kutatás, mely egy alacsony vagy közepes jövedelmú országban vizsgálja egy, az egész iskolára kiterjedő többtényezős egészségfejlesztő beavatkozás eredményességét és költséghatékonyságát az Egészségügyi Világszervezet (World Health Organization, WHO) egészségfejlesztő iskola koncepciója jegyében. Jelen tanulmány szerzői kutatásukban azt vizsgálták, hogy mi történik akkor, ha nem az iskola valamely alkalmazottja (tanár vagy egészségügyi szakember) vesz részt a beavatkozásban - ahogyan ez a Bihár állambeli iskolákban általában lenni szokott -, hanem egy külső, nem pedagógus végzettségú munkatárs, akit nem terhelnek az iskolai teendők és feladatok. A beavatkozás költséghatékonyságát növelte, hogy a külső munkatárs felkészítése csupán egy hetet vett igénybe.

A vizsgálat elsődlegesen arra fókuszált, hogy egy tanév alatt miként változik az iskolai klíma a SEHER egészségfejlesztő program hatására, ami egyaránt tartalmazott az egész iskolát érintő, osztályszintű és

i A SEHER betűszó a Serdülőkorúak egészségfejlesztését szolgáló, bizonyítékon-alapuló iskolai beavatkozások Bihár államban, Indiában cím angol megfelelőjéből került kialakításra. 
egyéni beavatkozásokat. Mivel a diákok által észlelt iskolai klíma összefüggésbe hozható számos egészséggel kapcsolatos tényezővel és magatartással (pl. érzelmi jóllét, iskolai erőszak, reprodukciós egészség), ezért a vizsgálat másodlagosan kiterjedt a diákok körében tapasztalható depresszió, zaklatás, áldozattá válás, nemek közötti egyenlőség iránti attitűd és a reprodukciós egészséggel kapcsolatos tudás mérésére is.

A kutatásban 75 Bihár állambeli iskola vett részt; az iskolákat véletlenszerűen három csoportba osztották: az első csoportba kerülő iskolák számára a SEHER egészségfejlesztő programot egy külsős, nem pedagógus végzettségű személy koordinálta. A második csoportba kerülő iskolák esetében ugyanezt a programot egy, az adott iskolában dolgozó pedagógus vezette, míg a harmadik csoportba kerülő iskolákban egy hagyományos, életvezetési készségekre fókuszáló és az ottani állami fenntartású iskolákban általánosan elterjedt serdülőkre irányuló programot alkalmaztak.

\section{EREDMÉNYEK}

Az első csoportba került iskolák esetében a tanév végére jelentősen javult az iskolai klíma, valamint az összes fentebb említett egészséggel kapcsolatos tényező vonatkozásában közepes vagy jelentős mértékú javulás mutatkozott, míg a második és a kontrollcsoportba került iskolák esetében alig volt kimutatható változás. Vagyis azok az iskolák, ahol az egészségfejlesztő beavatkozást az iskolától független, nem pedagógus végzettségü személy koordinálta, minden mért tényező tekintetében jobban teljesítettek, mint azok az iskolák, ahol a tantestület tagja közvetítette ugyanezt a beavatkozást. A tanulmány szerzői szerint eredményeik összhangban vannak az egészségfejlesztő iskolákkal kapcsolatos eddigi kutatásokkal, vagyis egy komplex, egész iskolára kiterjedő egészségfejlesztő beavatkozás javítja az iskolai társas környezet minőségét és ezáltal hozzájárul a diákok jobb mentális egészségéhez, valamint az iskolai erőszak csökkenéséhez. Az viszont, hogy miért nem volt jelentős hatása az iskolai klímára a pedagógusok által vezetett beavatkozásnak a külső, nem pedagógus munkatársak által koordinált beavatkozáshoz képest, további vizsgálatokat igényel. Lehetséges magyarázat lehet, hogy a külső munkatársak kizárólag az egészségfejlesztő beavatkozásért voltak felelősek és nem terhelték őket a pedagógusokra nehezedő oktatási és adminisztratív feladatok. További magyarázat lehet, hogy a pedagógusok nem tudtak hatékonyan váltani az egészségfejlesztő program facilitátori szerepe és a tanárszerep között. Ugyancsak elképzelhető, hogy a diákok számára sem volt egyértelmú, hogy mikor milyen kérdésekkel fordulhatnak a beavatkozást vezető pedagógushoz, ezért összességében ezekben a beavatkozásokban sokkal kevesebb interakcióra került sor, emiatt maradhatott el a hatékonyság a külső munkatársak által vezetett beavatkozásokhoz képest.

\section{TANULSÁGOK A HAZAI SZAKEMBEREK SZÁMÁRA}

Magyarországon jelenleg kevés törekvést találunk arra, hogy igazoltan hatékony és komplex egészségfejlesztő beavatkozások valósuljanak meg az iskolákban. Bár az iskolai egészségfejlesztésben mind a pedagógusoknak, mind az iskolaorvosoknak, iskolai védőnőknek, iskolapszichológusoknak szerepük van, az a tendencia tapasztalható, hogy egyéb feladataik és leterheltségeik miatt kevésbé tudnak aktívan részt venni az iskolai egészségfejlesztő munkában. A cikk tanulsága, hogy pontosan emiatt, hatékonyabb lehet, ha olyan személy - akár tantestületen kívüli - koordinálja az egészségfejlesztő beavatkozást, akinek kizárólag ez a feladata. 